\title{
Comparative Analysis of Food Expenditure Pattern of Nepalese Households Using Engel Curves
}

\author{
Bishu Khanal ${ }^{1}$, Kamal Banskota $^{2}$ and Dhiraj Giri ${ }^{3}$
}

\begin{abstract}
The study examined the effects of demographic and non-demographic factors like income, family size, rural/urban location of household and gender of household head on consumption expenditure across 9 different food commodities. To analyze the food consumption behavior of Nepalese households National Living Standard Survey (NLSS) over two years 1995/96 and 2010/11 have been used. This study found that there have been significant changes in food consumption pattern in Nepal during these two periods. Food budget share of a household has declined over time. Budget share of cereals and pulses has shifted towards other food items such as fruits, vegetables, meat, dairy products and other miscellaneous food items. Result also shows that lower income households have higher expenditure elasticities of food compared to higher income households. Similarly, rural households have higher expenditure elasticities of food compared to urban households. For male and female headed households, expenditure elasticities are almost similar for major food categories. Diseconomies of scale are found in food expenditure as an additional family member would increase additional expenditure on food. The findings of this study are significant as they would serve as important policy guidelines and basis for further studies.
\end{abstract}

Keywords: expenditure elasticity; economies of scale; food expenditure; Engle curve and Nepalese households

\section{Introduction}

Food consumption is a key determinant of nutritional adequacy and overall health of the population of a country. A healthy population provides human capital and productive labor force essential for fueling economic growth and productivity. However, currently about one-eighth of total world population suffers from chronic hunger (FAO;IFAD;WFP, 2013). Most of the hungry people live in poor countries where poor public health related with food deficiency is one of the main hindrances for economic growth. Though food expenditure in poor countries accounts for

\footnotetext{
${ }^{1}$ Correspondent Author

${ }^{2}$ Visiting Faculty, Kathmandu University School of Arts

${ }^{3}$ Associate Professor, Kathmandu University School of Arts
} 
majority of total consumption expenditure, food intake is insufficient and is aggravated by disparity of food access among different socio-economic groups.

Nepal's condition is no different from most of the other poor countries. Food security is a significant problem where about one-quarter of total population live under the national poverty line. Over the last two decades agricultural production in the country has not been able to keep pace with the population growth rate. Unequal distribution of food and nutrition among different population groups is a fundamental problem. According to Regmi (2016), prevalence of food inadequacy and undernourishment was 19\% and 13\% respectively in Nepal in the year 2013 . Among children under-5 years old the prevalence of stunting and wasting is $40 \%$ and $11 \%$ respectively(USAID Nepal, 2017).Identifying and understanding food consumption behavior of vulnerable groups is essential for the government to implement effective policies and address short and long term issues of food security.

The Engel curve is an important economic tool that establishes relationship between household's total expenditure and expenditure on a particular food item. The proposed research tries to estimate the Engel curve to explore food expenditure pattern of households in Nepal using two rounds of Nepal Living Standard Survey (NLSS) data, 1995/96 and 2010/11. The study analyzes 9 different food commodity groups to see the extent of change in household food consumption behavior over this period. It also identifies demographic and nondemographic factors like location of household, family size, dependency ratio, land and livestock ownership, and gender, education and income level of household head that might explain the variation in food consumption.

The study of change in food consumption behavior in Nepal between the period of 1996 and 2011 is of particular importance because Nepal went through major political and socio-economic changes during this period. It was a period when Maoist insurgency took place in which about 18,000 Nepalese people were killed. Maoist conflict changed social and population dynamics of the country as many people moved towards urban areas in search of better security. Increasing number of people migrated abroad for employment opportunities. The incidence of poverty fell from $42 \%$ in 1995 to $25 \%$ in 2011 (CBS, 2011). The share of agriculture in GDP decreased from $41.75 \%$ in 1995 to $38.30 \%$ in 2011(World Bank, 2017). Contribution of external sectors also changed as imports increased exponentially while exports dwindled. Remittance became an important part of the economy as its share in GDP increased from 1.29\% in 1995 to $22.30 \%$ in 2011(World Bank, 2017). All these socio-economic changes may have changed household food consumption behavior. It is imperative to study changes in such behavior that have significant policy implications. 
It is important to analyze the variation in food consumption as findings of such analysis have important policy implications. They help to forecast food demand of the country so that the government can make investment decisions on production sectors accordingly. Food supply in Nepal is vulnerable as production is subject to shortages and high price fluctuations with slightest change in factors like weather and labor availability. Though there was surplus of food production in the past, Nepal has experienced food deficit in recent years which has to be fulfilled through increasing imports. Poorer households get affected by this as they lack access to credit, finance and transportation facilities to be able to purchase imported items. If we can make precise projection of food demand, domestic production could be enhanced to meet food requirement.

The study of food expenditure behavior goes a long way in identifying and addressing the needs of vulnerable groups and reducing the prevalence of food insecurity in the country. Study of food expenditure behavior of households using Engel curve was made popular in 1980s and 1990s in other advanced economies. However, substantial quantitative research studying food expenditure in Nepal is lacking. As Nepal is still in political transition, most of the economic studies are tactical, focusing on mitigating immediate crisis stemming from political instability. Therefore, the present research strives for a strategic goal -contributing to long term food policies.

The Structure of this study is organized as follows. Section 2 presents literature review and section 3 discusses study methodology that contains theoretical framework, model specification, description of data sources and variables. Section 4 presents descriptive statistics with summary of food expenditure among different partitions. Section 5 consists of empirical analysis. Section 6 concludes with concluding remarks.

\section{Literature Review}

Many empirical studies have been carried out utilizing conceptual framework of the Engel curve to study consumption pattern of households. Different econometric models have been proposed and used to estimate the Engel curves for various commodities. Prais and Honthakker (1955) and Banskota et al.(1986) have used semi-logarithmic model to estimate Engel curve for food and non-food commodities. The authors have found that there is higher expenditure elasticity for all commodities for lower income households. All food and non-food items are luxuries for lower income households while for higher income households only non-food items are luxuries. Higher income households also experience greater economies of scale compared to lower income households. 
Deaton and Muellbauer (1980); Pradhan and Tuwade (1997) have used linear approximation of Almost Ideal Demand System (AIDS) function to study consumption patterns of households. They have found that expenditure elasticities for all food categories are positive indicating that they are normal goods. It is also found that food and housing are necessities while other goods are luxuries. Some food items that are luxuries at one time period turn out to be necessities during other period and vice versa. Expenditure elasticities also vary over time suggesting structural transformation on demand for food over time. Demographic factors do affect demand of food items. Larger families consume more of basic food like rice, cereals and milk products. However urban as well as better educated families consume more of vegetables, meat, fish and fruits.

Banks, Blundell and Lewbel (1997); Molina (1994); Mittal (2010) and Kumar et al. (2011) have used Quadratic version of AIDS (QUAIDS) model to estimate the Engel curves for consumer demand. The authors have found that linearity of expenditure holds for food commodities but not for others. Commodities show characteristics of being both luxuries and necessities at different income levels. Income elasticities for food items are lower in urban areas compared to elasticities in rural areas. Though budget allocation for cereals is the highest, over time it shifts from cereals to fruits, vegetables, meat and dairy products.

Khan and Khalid (2010); and Kiani (2013) have studied household consumption pattern of Pakistan using double logarithmic form. Their results indicate that expenditure elasticities are the highest for housing, food, drinks and miscellaneous products. Rural households tend to spend more on food and drinks, clothing and foot wear, transportation, communication and health care. Urban households spend more on education, housing and durables. Over time most significant changes have been pronounced in expenditure of education for both urban and rural households.

Al-Habashneh and Al-Majali (2014) have used six different functional forms to estimate the Engel curves for household expenditures in Jordan. The results from linear form, logarithmic form and semi-logarithmic form are plausible from both statistical and economical point of view for most of the commodities under study. Coefficient of parameters and intercept estimates are statistically significant with relatively high value of $\mathrm{R}^{2}$. Sum of weighted budget shares equal to unity that satisfies the condition of Engel aggregation. For all functional forms that are estimated, demand for food and health commodities is not relatively elastic with respect to total expenditure while demand for housing, transportation, personal care and miscellaneous items is relatively elastic. The consumption pattern of both rural and urban areas is same for commodities like food, household operation, transportation and health items. Economies of scale prevail for food consumption because as the family size increases per-capita food expenditure decreases. However, there are diseconomies of scale for transportation, personal care and miscellaneous items. 


\section{Methodology}

\subsection{Conceptual Model}

The study uses the theory of consumer behavior of utility maximizing individual to analyze the consumption behavior of Nepalese household. ${ }^{4}$ Utility function for $n$ number of commodity bundle $\mathrm{X}$ can be expressed as:

$$
U=U_{1}\left(x_{1}\right)+U_{2}\left(x_{2}\right)+\cdots \ldots \ldots U_{i}\left(x_{n}\right)
$$

An individual attempts to purchase most preferred commodity bundle given his budget constraints which is given by

$$
p_{1} x_{1}+p_{2} x_{2}+\ldots+p_{n} x_{n}=Y
$$

where, $p_{1}, p_{2}, \ldots p_{n}$ represents unit prices of commodity bundles $x_{1}, x_{2} \ldots . x_{n}$ and $Y$ represents income of an individual. The consumer's choice of commodity bundles $x 1, x 2 \ldots \ldots x n$ will correspond to quantities obtained by the maximization of

$$
U\left(x_{1}, x_{2} \ldots x_{n}\right)+\lambda\left(y-p_{1} x_{1}-p_{2} x_{2}-\ldots-p_{n} x_{n}\right)
$$

Differentiating equation (3) with respect to $x_{1}, x_{2} \ldots \ldots x_{n}$ and $\lambda$, we get the following equations.

$$
\left.\begin{array}{c}
u i\left(x_{1}, x_{2} \ldots x_{n}\right)-\lambda p_{i}=0, \quad i=1, \ldots . n \\
Y-p_{1} x_{1}-p_{2} x_{2}-\ldots . p_{n} x_{n}=0
\end{array}\right] \text { (4) where, } u_{i}=\frac{\partial U}{\partial x_{i}}
$$

When all the prices and income are given the above system (4) provides $(n+1)$ equations in $(n+1)$ variables $\left(x_{1}, x_{2} \ldots \ldots x_{n}\right.$ and $\left.\lambda\right)$ and hence can find the values for the unknowns that maximize the individual's satisfaction. We can express quantity of each commodity in terms of its own price, price of other commodities and income in the form:

$$
\begin{aligned}
& x_{j}=x_{j}\left(p_{1}, p_{2}, \ldots \ldots, p_{n}, y\right) \\
& \text { for } j=1 \text { to } n
\end{aligned}
$$

The relationship expressed in equation (5) is called demand function. Multiplying both sides of this equation by $p_{j} / y$, we get

$$
\frac{p_{j} x_{j}}{y}=\frac{p_{j} x_{j}}{y}\left(p_{1}, p_{2}, \ldots \ldots \ldots p_{n}, y\right)=w_{j}
$$

\footnotetext{
${ }^{4}$ Utility theory, in this study, is summarized from the article George and King (1971). Therefore for detailed information regarding derivation of demand theory it could be referred to the mentioned article.
} 
where, $w_{j}$ is a budget share of $\mathrm{j}^{\text {th }}$ commodity.

The Engel curve is the study of relationship between budget allocated on a particular commodity and total income where effects of price changes are held constant. It can be expressed mathematically as

$$
\begin{aligned}
& w_{i}=\alpha_{i}+\beta_{i} Y \\
& \left(\sum \alpha_{i}=0 \text { and } \sum \beta_{i}=1 \text { as implied by adding up conditions }\right)
\end{aligned}
$$

where, $\mathrm{Y}$ is the total income, $\alpha_{i}$ is the intercept coefficient and $\beta_{i}$ is the income coefficient. Cross section data are generally used to estimate the Engel curve in which relative prices to households are assumed to be constant (Banskota et al., 1986).According to the assumption of the Engel curve, change in income share spent on a particular food item is inversely related with change in total household income. This study utilizes total consumption expenditure of household as a substitute for income which is a general convention while estimating the Engel curve (Banskota et al., 1986) and (Khan \& Khalid, 2010).

Choice of functional forms in estimating Engel curve is an important issue that is discussed in many empirical studies. There is no superiority of any specific functional forms to be used for the estimate of Engel curves. The study uses semilogarithmic function because of its popularity in other similar studies so that it would be easier to compare results. The use of semi-log function is also appropriate because it establishes relation between total expenditure and expenditure on particular item without the influence of changing price making it easier to compare food expenditure among different income groups.

\subsection{Model Specification}

The study utilizes the semi-log Engel curve which can be derived from utility maximization when prices are kept constant. Engel aggregation, one of the relevant demand restrictions when prices are kept constant, is satisfied through semi-log model with budget shares as dependent variables. Many studies including Prais \& Honthakker (1955), Banskota et al. (1986) and Al-Habashneh \& Al-Majali (2014) have used the application of semi-log to estimate the Engel curve. The semi-log Engel curve can be written as

$$
w_{i}=\alpha_{i}+\beta_{i} \log Y+\sum \gamma_{i} Z_{i}+u_{i}
$$

where $w_{i}$ is the $\mathrm{i}^{\text {th }}$ budget share, $\mathrm{Y}$ is the total expenditure, $z_{i}$ is the $\mathrm{i}^{\text {th }}$ demographic variable and $\alpha_{i}, \beta_{i}, \gamma_{i}$ are parameters to be estimated and $u_{i}$ is residual. Expenditure elasticity of demand for the specified model can be derived as

$$
\eta_{i}=1+\beta_{i} / w_{i}
$$


Expenditure elasticity is defined as percentage change in expenditure of a particular commodity with percentage change in total expenditure. Magnitude and sign of expenditure elasticity can be used to determine whether a commodity is necessity, inferior or normal good. The commodity is categorized as luxury if $\eta_{i}>$ 1 , necessity if $1>\eta_{i}>1$ and inferior if $\eta_{i}<0$.

In addition to using total consumption expenditure as independent variable other socio-economic and demographic variables are also used to study the variation in food expenditure. Variables like remittance income, family size, urban or rural location of household and education, ethnicity and gender of household heads have been used by Pradhan \& Tuwade (1997), Kiani (2013), Gupta \& Mishra (2014) and Al-Habashneh \& Al-Majali (2014) to explain food expenditure. With inclusion of the variables explained in the above section the specified model can be expressed as

$w_{i}=\alpha_{i}+\beta_{i} \log Y+\gamma_{1} E d+\gamma_{2} A L+\gamma_{3} V L+\gamma_{4} D+\gamma_{5} F S+\gamma_{6} F S^{2}+u_{i}$.

Economies of scales can be derived from the model as

$$
E_{i}=\left(\gamma_{5} F S+2 \gamma_{6} F S^{2}\right) / w_{i}
$$

Economies of scale can be defined as decrease in additional expenditure on a commodity per increase in additional member of household.

\section{Descriptions of variables}

Dependent variable used in the study

$W i=(E i / T E)$ which is a budget share of $i^{t h}$ food category where TE is total consumption expenditure.

It is a percentage of expenditure that a household allocates on a particular food category out of its total consumption expenditure. Total consumption expenditure is computed by aggregating expenditure on food and non-food items but exclude inventories of durable goods. It is a common practice to use budget share as dependent variable while studying consumption pattern as done in Deaton \& Muellbauer (1980), Banskota et al. (1986), Pradhan \& Tuwade (1997) and AlHabashneh \& Al-Majali (2014).

List of independent variables used in the study

- $\quad \mathrm{TE}=$ Total consumption expenditure

- $\quad \mathrm{Ed}=$ Years of formal education of household head

- $\quad \mathrm{FS}=$ Family size (number of family members)

- $\quad \mathrm{FS}^{2}=$ Square of family size

- $\mathrm{D}=$ Dependency ratio 
- $\quad \mathrm{AL}=$ Area of land owned by household

- $\quad \mathrm{VL}=$ Value of livestock owned by household

\subsection{The Data}

The study uses the data from Nepal Living standard Survey (NLSS) which is done with the primary objective of measuring living standard of Nepalese people and determining level of their poverty. It has become popular among government, international organization and general public to carry out studies that are important in decision making. Various topics related to demography, consumption, income, health, education, income and remittances are included in the survey. The survey has followed the Living Standards Measurement Survey (LSMS) methodology developed and promoted by the World Bank. Until now, NLSS has been carried out on three different years 1995/96, 2003/04 and 2010/11. Since the NLSS in 2003/04 was carried out in the midst of Maoist insurgency, data in this survey might not reflect actual scenario. Therefore, this study has only used the data from NLSS 1995/96 and 2010/11. Another reason for using data from only these two rounds is to compare the scenarios before and after Maoist conflict. CBS (2011) can be referred to learning in detail about the methodology used to collect data in NLSS. In this study, the analysis of household food consumption pattern is carried out for 9 different food commodity groups. The details of food products incorporated in these 9 broad categories are listed below.

- Cereals and Pulses: Fine rice, coarse rice, beaten rice, maize, wheat, millet, black gram, lentils, red gram, Horse gram, beans and others

- Meat and dairy Products: Eggs, milks, condensed milks, curd, fish, mutton, buffalo meat, chicken and others

- Fruits and Vegetables: Potatoes, onions, cauliflower/cabbage, tomatoes, green leafy vegetables, gourd, banana, citric fruits, mango, apple, pineapple, papaya, dried fruits and others

- Cooking oils: Ghee, vegetable oil, mustard oil and other oils

- Sweets and spices: Salt, black pepper, turmeric, ginger/garlic, chilies, sugar, gunr, sweets and others

- Non-Alcoholic Beverages: Tea, coffee, fruit juices, carbonated drinks and other non-alcoholic drinks

- Alcoholic Beverages: Wine, gin, whisky and others

- Tobacco and Tobacco products: Cigarettes, bidis, tobacco and others

- Miscellaneous Food Products: Meals taken outside home, breads, biscuits, noodles and others

The food items are divided into 9 different commodity groups because items in each category have similar characteristics in terms of nutritional value they provide 
and other purposes they serve. An average Nepalese household spends significant amount of its budget in each of these food categories. Therefore, analyzing expenditure of households in these food categories helps us understand their consumption behavior and source of nutrition for them.

\section{Descriptive Statistics}

Table 1: Food expenditure of Nepalese households between 1996 and 2011

\begin{tabular}{clllllllll}
\hline Year & \multicolumn{2}{c}{ Actual Expenditure (AE) $\begin{array}{l}\text { Per-Capita Expenditure } \\
\text { (PCE) }\end{array}$} & \multicolumn{3}{c}{$\begin{array}{l}\text { Food Budget Share } \\
\text { (BS) }\end{array}$} \\
\cline { 2 - 10 } & Mean(Rs) & S.D. & $\begin{array}{l}\text { Coe. } \\
\text { V Mean(Rs) }\end{array}$ & S.D & Coe. V & Mean & S.D. & $\begin{array}{l}\text { Coe. } \\
\text { V }\end{array}$ \\
\hline 1996 & 3,694 & 2,335 & $63 \%$ & 729 & 451 & $62 \%$ & 0.79 & 0.16 & $20 \%$ \\
2011 & 12,398 & 6,431 & $52 \%$ & 2,914 & 1,594 & $55 \%$ & 0.67 & 0.19 & $28 \%$ \\
\hline
\end{tabular}

Note: S.D.= Standard Deviation $\quad$ Coe.V $=$ Coefficient of Variation

Mean actual food expenditure of households in nominal terms increased from RS 3,694 to RS 12,398 between 1996 and 2011, an average annual increase of about $8.41 \%$. Increase in food expenditure of households is explained by an annual increase in nominal income of households between the same time periods which was $10.1 \%$. However, mean actual expenditure in 2011 expressed in real terms on 1996 price would be RS 4,113. This amounts to average annual increase in food expenditure of $0.72 \%$.But variability in actual food expenditure decreased from $63 \%$ in 1996 to $52 \%$ in 2011 . Nominal per-capita food expenditure increased from RS 729 to RS 2,914 at an annual rate of $9.68 \%$ while variability decreased from $62 \%$ to $55 \%$. Food budget share decreased from $79 \%$ to $67 \%$ while variability of food budget share increased from $20 \%$ to $28 \%$.

Table 2: Percentage of food expenditure by food category between 1996 and 2011

\begin{tabular}{lllll}
\hline Year/Food Category & \multicolumn{2}{c}{$\mathbf{1 9 9 6}$} & \multicolumn{2}{c}{$\mathbf{2 0 1 1}$} \\
\cline { 2 - 5 } & Mean (\%) & S.D. (\%) & Mean (\%) & S.D. (\%) \\
\hline 1.Cereals and Pulses & 53 & 17 & 37 & 14 \\
2. Meat and Dairy Products & 15 & 9.4 & 20 & 9.2 \\
3. Fruits and Vegetables & 13 & 7.2 & 17 & 6.8 \\
4. Cooking Oils & 6.2 & 3.9 & 7.3 & 3.7 \\
5. Sweets and Spices & 5.0 & 3.2 & 6.8 & 2.9 \\
6. Non-Alcoholic Beverages & 1.0 & 1.7 & 1.5 & 1.8 \\
7. Alcoholic Beverages & 2.6 & 5.2 & 3.0 & 5.3 \\
8. Tobacco and Tobacco Products & 1.7 & 2.6 & 1.3 & 2.5 \\
9. Miscellaneous Food & 3.2 & 6.3 & 6.2 & 7.8 \\
\hline
\end{tabular}

Cereals and pulses are food crops that occupied largest budget share of Nepalese households followed by meat and dairy products, fruits and vegetables, and 
cooking oils. Food budget share for cereals and pulses declined between 1996 and 2011 while share for other major food categories increased. Nepalese households begin to diversify their food consumption from cheap carbohydrates to high value nutrition such as proteins, vitamins and fats. Budget share for miscellaneous food products also rose significantly from $3.2 \%$ in 1996 to $6.2 \%$ in 2011 . It means people begin to spend more on food taken away from home and on other commercial food items such as breads, biscuits and noodles.

Table 3: Budget share of major food categories by expenditure group between 1995 and 2011

\begin{tabular}{|c|c|c|c|c|c|c|c|c|}
\hline Year & & & 1996 & & & & 2011 & \\
\hline $\begin{array}{l}\text { Expenditure } \\
\text { Group(Rs) }\end{array}$ & $\begin{array}{l}\text { Cereals } \\
\text { and } \\
\text { Pulses }\end{array}$ & $\begin{array}{l}\text { Meat } \\
\text { and } \\
\text { Dairy } \\
\text { Products }\end{array}$ & $\begin{array}{l}\text { Fruits and } \\
\text { Vegetables }\end{array}$ & $\begin{array}{l}\text { Misc. } \\
\text { Food } \\
\text { Products }\end{array}$ & $\begin{array}{l}\text { Cereals } \\
\text { and } \\
\text { Pulses }\end{array}$ & $\begin{array}{l}\text { Meat } \\
\text { and } \\
\text { Dairy } \\
\text { Products }\end{array}$ & $\begin{array}{l}\text { Fruits and } \\
\text { Vegetables }\end{array}$ & $\begin{array}{l}\text { Misc. } \\
\text { Food } \\
\text { Products }\end{array}$ \\
\hline $0-5000$ & $55 \%$ & $14 \%$ & $13 \%$ & $2.9 \%$ & $41 \%$ & $16 \%$ & $17 \%$ & $4.4 \%$ \\
\hline $5000-10000$ & $52 \%$ & $16 \%$ & $13 \%$ & $3.5 \%$ & $40 \%$ & $18 \%$ & $17 \%$ & $4.6 \%$ \\
\hline $10000-15000$ & $48 \%$ & $17 \%$ & $13 \%$ & $3.9 \%$ & $39 \%$ & $19 \%$ & $17 \%$ & $4.9 \%$ \\
\hline $15000-20000$ & $42 \%$ & $20 \%$ & $15 \%$ & $4.2 \%$ & $37 \%$ & $20 \%$ & $17 \%$ & $5.6 \%$ \\
\hline $\begin{array}{l}20000 \& \\
\text { above }\end{array}$ & $32 \%$ & $21 \%$ & $17 \%$ & $5.6 \%$ & $33 \%$ & $22 \%$ & $17 \%$ & $8.1 \%$ \\
\hline
\end{tabular}

Food budget share of cereals and pulses decreased significantly as total expenditure of household increased. Similarly for each expenditure group, the share decreased from 1996 to 2011. Households spent more on meat and dairy products as well as on miscellaneous food products with increase in total expenditure. The share of these food categories increased for each expenditure group from 1996 to 2011. Food budget share of fruits and vegetables was same for all other expenditure groups in 1996 except for 2 highest expenditure groups that had higher share. However budget share of fruits and vegetables was same for all expenditure groups in 2011. Overall, the results show that households diversified consumption towards more nutritious food as income increased.

As discussed above there were massive changes in food consumption behavior of Nepalese households between 1996 and 2011. Nominal food expenditure of households increased from RS 3,694 to RS 12,398, an average annual increase of about $8.41 \%$. Variability in food expenditure decreased from $63 \%$ to $52 \%$. Percapita food expenditure increased from RS 729 to RS 2914. Food budget share decreased from $79 \%$ to $67 \%$. There were changes in expenditure on major food categories as well. While cereals and pulses occupied the highest food budget share both in 1996 and 2011 their budget share decreased from 53\% to 37\%. Households diversified expenditure towards food like meat and dairy products, fruits and vegetables and miscellaneous food items. 


\section{Empirical Analysis}

\subsection{Chow Test}

Hypothesis for Chow test can formally be stated as:

Null Hypothesis $\left(H_{o}\right)$ :

There is no structural shift in food consumption between 1996 and 2011

Alternative Hypothesis $\left(H_{1}\right)$ :

There is a structural shift in food consumption between 1996 and 2011

$$
\text { Significance Level }(\alpha)=0.01
$$

Critical Value $=F_{0.01}(K, N-2 K)$

Test Statistics $=\frac{\left(R S S_{p}-\left(R S S_{1996}+R S S_{2011}\right)\right) / K}{\left(R S S_{1996}+R S S_{2011}\right) /(N-2 K)}$

Where

$$
\begin{gathered}
R S S_{p}=\text { Residual sum of square for pooled data } \\
R S S_{1996}=\text { Residual sum of square for } 1996 \text { data } \\
R S S_{2011}=\text { Residual sum of square for } 2011 \text { data } \\
N=\text { Total number of observations } \\
K=\text { Total number of parameters }
\end{gathered}
$$

For this study values for above statistics are:

$$
\begin{gathered}
R S S_{p}=181.44 \\
R S S_{1996}=55.22 \\
R S S_{2011}=101.09 \\
N=9361 \\
K=8
\end{gathered}
$$

Critical Value: $F_{0.01}(8,9345)=2.51$

Test Statistics $=187.80$

Since, Test statistics $>$ Critical Value, we reject $H_{0}$

We accept $H_{1}$ at 1 percent significant level. Therefore, it can be said from statistical point of view that there has been structural shift in food consumption of Nepal between 1996 and 2011. This result strengthens the argument that changes in socio-economic scenario of the country led to major changes in households' food consumption behavior. Since the relationship of food consumption between two periods is not stable, results are analyzed using separate regressions for data sets $1995 / 96$ and 200/11. 


\subsection{Regression Results of the Estimated Engel Curves}

Table 4: Estimated coefficients, expenditure and scale elasticities of food, Nepal (1996-2011)

\begin{tabular}{llllllll}
\hline Year & Intercept $\left(\boldsymbol{\alpha}_{\mathbf{i}}\right)$ & $\begin{array}{l}\text { Log- } \\
\text { Expenditure }\left(\boldsymbol{\beta}_{\mathbf{i}}\right)\end{array}$ & $\begin{array}{l}\text { Family } \\
\text { Size(FS) }\end{array}$ & $\begin{array}{l}\text { Family } \\
\text { Size }^{2} \\
\left(\mathbf{F S}^{2}\right)\end{array}$ & $\begin{array}{l}\text { Expenditure } \\
\left.\text { Elasticity( } \boldsymbol{\eta}_{\mathbf{i}}\right)\end{array}$ & $\begin{array}{l}\text { Scale } \\
\text { Elasticity } \\
\left(\mathbf{E}_{\mathbf{i}}\right)\end{array}$ & $\mathbf{R}^{2}$ \\
\hline 1996 & 1.74 & -0.29 & 0.02 & -0.001 & 0.63 & 0.06 & 0.46 \\
& $(56.25)$ & $(30.94)$ & $(9.67)$ & $(6.36)$ & & & \\
2011 & 2.60 & -0.49 & 0.03 & -0.001 & 0.27 & 0.15 & 0.53 \\
& $(93.70)$ & $(69.98)$ & $(15.25)$ & $(7.70)$ & & & \\
\hline
\end{tabular}

$\mathrm{t}$-values are presented in parentheses

The results of the estimates of semi-log Engel curves for food expenditure in Nepal are reported in table 4. Food budget share is used as dependent variables and total expenditure and family size are used as independent variables to estimate the Engel curves. Intercept coefficients as well as coefficients used to derive expenditure and scale elasticities are significant at $1 \%$ significance level. $\mathrm{R}^{2}$ values for the model is 0.46 and 0.53 for 1996 and 2011 data respectively. This means $46 \%$ variation in food budget share in 1996 and 53\% variation in 2011 is explained by independent variables. These low values of $\mathrm{R}^{2}$ indicate food budget share of households is explained poorly by total expenditure and family size alone. There might be other factors that influence household's food consumption behavior. However, low values of $\mathrm{R}^{2}$ are anticipated in cross section study (Banskota et al., 1986).

Expenditure elasticities of food demand are positive and less than 1 in 1996 and 2011. This means food was necessity in both periods. This is a priori knowledge in economies as explained by Deaton \& Muellbauer (1980), Pradhan \& Tuwade (1997) and Al-Habashneh and Al-Majali (2014). 10\% increase in total expenditure would increase food demand by $6.3 \%$ and $2.7 \%$ in 1996 and 2011 respectively. Though food was a necessity in both periods expenditure elasticity decreased from 1996 to 2011. Scale elasticities are positive in both periods. It means increase in family size would increase additional food expenditure. Increase in 1 family member would increase additional food expenditure by $0.06 \%$ and $0.15 \%$ in 1996 and 2011 respectively. Therefore there are diseconomies of scale in food consumption of Nepalese households. 
Table 5: Estimated coefficients and expenditure elasticities of food, low and high income households (1996-2011)

\begin{tabular}{|c|c|c|c|c|c|c|c|c|c|c|c|c|}
\hline \multirow{3}{*}{$\begin{array}{l}\text { Food } \\
\text { Category }\end{array}$} & \multicolumn{9}{|c|}{1996} & \multicolumn{3}{|c|}{2011} \\
\hline & \multicolumn{3}{|c|}{$\begin{array}{c}\text { Low Expenditure } \\
\text { Households(0-10,000) } \\
\text { RS } \\
\end{array}$} & \multicolumn{3}{|c|}{$\begin{array}{c}\text { High Expenditure } \\
\text { Households(10,000 } \\
\text { and above) RS }\end{array}$} & \multicolumn{3}{|c|}{$\begin{array}{c}\text { Low Expenditure } \\
\text { Households(0- } \\
\text { 10,000) RS } \\
\end{array}$} & \multicolumn{3}{|c|}{$\begin{array}{c}\text { High Expenditure } \\
\text { Households(10,000 } \\
\text { and above) RS }\end{array}$} \\
\hline & & & $\mathrm{R}^{2}$ & $\alpha_{i}$ & $\eta_{i}$ & $\mathrm{R}^{2}$ & $\alpha_{i}$ & $\eta_{\mathrm{i}}$ & $\mathrm{R}^{2}$ & $\alpha_{i}$ & $\eta_{\mathrm{i}}$ & $\mathrm{R}^{2}$ \\
\hline De & 1. & & 0.19 & 2.65 & 0.02 & 0.38 & 1.59 & 0.71 & 0.1 & 2.90 & 0.14 & 0.54 \\
\hline 000 & $(40.64)$ & $(11)^{\circ}$ & & $(9.50)$ & $(8.60)$ & & $(16.3$ & $(8$. & & $(78.39)$ & $(63.89)$ & \\
\hline
\end{tabular}

Table 5 presents intercept coefficients and expenditure elasticities of low and high income households. All coefficients are significant at $1 \%$ significance level. $\mathrm{R}^{2}$ values for low expenditure households are relatively low compared to values for high expenditure households. Expenditure elasticities of food for both household groups are between 0 and 1 suggesting food is necessity. However they are high for low expenditure households and low for high expenditure households as anticipated (Banskota et al., 1986).10\% increase in total expenditure for low income households would increase food expenditure by $7.7 \%$ and $7.1 \%$ in 1996 and 2011 respectively. For high expenditure households 10\% increase in total expenditure would increase food expenditure by $0.2 \%$ and $1.4 \%$ in 1996 and 2011 respectively.

Table 6: Estimated coefficients and expenditure elasticities of major food category, Nepal (1996-2011)

\begin{tabular}{|c|c|c|c|c|c|c|c|c|c|c|c|c|c|c|}
\hline \multirow{2}{*}{$\begin{array}{l}\text { Food } \\
\text { Category }\end{array}$} & \multicolumn{6}{|c|}{1996} & \multicolumn{8}{|c|}{2011} \\
\hline & $\overline{\alpha_{i}}$ & $\eta_{i}$ & Ed & VL & $\mathbf{A L}$ & D & $\mathbf{R}^{2}$ & $\boldsymbol{\alpha}_{\mathrm{i}}$ & $\eta_{i}$ & Ed & \multirow{2}{*}{$\frac{V L}{0 \Omega 0}$} & $\mathbf{A L}$ & D & $\mathbf{R}^{2}$ \\
\hline \multirow{2}{*}{$\begin{array}{l}\text { Cereals } \\
\text { and Pulses }\end{array}$} & 1.19 & 0.40 & -0.01 & 0.03 & 0.07 & 0.01 & \multirow[t]{2}{*}{0.28} & 1.20 & 0.04 & 0.00 & & 0.02 & 0.02 & 0.37 \\
\hline & (32.07) & $(22.60)$ & (14.99) & $(2.06)$ & $(4.28)$ & $(2.02)$ & & $(50.23)$ & $(42.24)$ & $(12.21)$ & $(7.78)$ & $(2.05)$ & (9.93) & \\
\hline Meat and & 0.12 & 0.81 & 0.002 & 0.00 & 0.00 & 0.01 & 0.03 & 0.36 & 0.54 & 0.001 & 0.30 & 0.00 & 0.00 & 0.12 \\
\hline Dairy & $(5.96)$ & $(2.35)$ & $(5.41)$ & (6.97) & $(3.59)$ & (3.28) & & (24.26) & (15.11) & $(2.32)$ & $(22.31)$ & (1.67) & (2.31) & \\
\hline \multicolumn{15}{|l|}{ Products } \\
\hline Fruits and & 0.22 & 0.70 & 0.001 & 0.04 & 0.16 & 0.00 & 0.06 & 0.45 & 0.27 & 0.001 & 0.05 & 0.01 & 0.00 & 0.15 \\
\hline Vegetables & (15.85) & $(7.41)$ & $(4.89)$ & $(2.47)$ & $(9.24)$ & $(0.25)$ & & (42.04) & (29.82) & $(4.14)$ & (3.91) & $(0.84)$ & (1.23) & \\
\hline Cooking & 0.15 & 0.40 & 0.00 & 0.14 & 0.01 & 0.00 & 0.09 & 0.21 & 0.20 & 0.00 & 0.15 & 0.06 & 0.00 & 0.15 \\
\hline Oils & (19.97) & (11.67) & $(6.77)$ & (7.98) & $(0.42)$ & $(3.63)$ & & (35.32) & $(26.20)$ & $(3.23)$ & (11.58) & (4.74) & $(1.45)$ & \\
\hline Sweets & 0.10 & 0.50 & 0.00 & 0.00 & 0.00 & 0.00 & 0.04 & 0.21 & 0.03 & 0.00 & 0.00 & 0.00 & 0.00 & 0.17 \\
\hline and Spices & $(15.58)$ & $(8.16)$ & $(0.67)$ & $(4.44)$ & $(0.83)$ & $(2.03)$ & & (42.44) & $(31.73)$ & $(4.71)$ & $(0.21)$ & $(0.00)$ & $(0.30)$ & \\
\hline Non- & -0.14 & 2.17 & 0.00 & -0.08 & -0.06 & 0.00 & 0.06 & 0.00 & 1.33 & 0.00 & -0.15 & -0.12 & 0.00 & 0.13 \\
\hline Alcoholic & $(4.71)$ & (7.42) & $(6.49)$ & $(4.28)$ & $(3.33)$ & $(1.25)$ & & $(1.07)$ & (5.10) & (15.28) & (11.15) & $(0.93)$ & $(4.21)$ & \\
\hline \multicolumn{15}{|l|}{ Beverages } \\
\hline Alcoholic & -0.03 & 2.00 & -0.001 & 0.00 & 0.00 & 0.00 & 0.03 & 0.08 & 0.25 & -0.001 & 0.00 & 0.00 & 0.00 & 0.02 \\
\hline Beverages & (3.18) & $(5.86)$ & $(5.59)$ & (2.94) & $(4.90)$ & (1.31) & & $(9.04)$ & $(6.81)$ & $(5.03)$ & $(1.20)$ & $(4.05)$ & $(5.42)$ & \\
\hline Tobacco & 0.04 & 0.23 & 0.00 & 0.00 & 0.00 & 0.00 & 0.02 & 0.01 & -0.11 & 0.00 & 0.00 & 0.00 & 0.00 & 0.03 \\
\hline and & $(8.31)$ & $(4.56)$ & $(0.65)$ & $(2.38)$ & (3.84) & $(0.87)$ & & (12.50) & $(9.54)$ & $(4.77)$ & $(3.07)$ & $(0.03)$ & $(8.22)$ & \\
\hline \multicolumn{15}{|l|}{ Tobacco } \\
\hline \multicolumn{15}{|l|}{ Products } \\
\hline Misc. & -0.02 & 2.00 & 0.00 & 0.00 & 0.00 & 0.00 & 0.02 & 0.04 & 1.00 & 0.00 & -0.15 & -0.01 & 0.00 & 0.05 \\
\hline Food & $(1.35)$ & $(2.84)$ & $(0.41)$ & $(4.40)$ & $(2.88)$ & $(2.65)$ & & (3.64) & $(1.22)$ & $(7.03)$ & $(10.3$ & $(0.66$ & $(5.49)$ & \\
\hline Products & & & & & & & & & & & & & & \\
\hline
\end{tabular}


Table 6 provides values of coefficients for intercepts, expenditure elasticities and other independent variables that explain the variation in expenditure on major food categories. Coefficients for intercepts and expenditure elasticities for most of the food categories are significant at $1 \%$ significance level. Values of $\mathrm{R}^{2}$ for cereals and pulses are around $30 \%$ but for other food items they are quite low. Cereals and pulses, fruits and vegetables, meat and dairy products, cooking oils and sweets and spices were necessities during both periods 1996 and 2011 as their expenditure elasticities are positive and less than 1. Non-alcoholic beverages and miscellaneous food products were luxuries during both 1996 and 2011 though their expenditure elasticities decreased. Expenditure elasticity for tobacco is positive in 1996 but negative in 2011 indicating it becomes inferior over time. This is due to the increasing awareness among people through campaigns and advertisements about negative health effects of tobacco products.

Coefficients of education are positive for meat and dairy products as well as for fruits and vegetables. It means expenditure on these food items would increase with increase in education. However education elasticities for alcoholic beverages are negative. Increase in value of livestock owned by households would increase consumption of cereals and pulses, meat and dairy products, fruits and vegetables and cooking oils. In Nepal, livestock is direct source of meat and dairy products as well as cooking oils for most of the rural households. Expenditure on non-alcoholic beverages would decrease with increase in value of livestock. Increase in area of land owned would increase expenditure on cereals and pulses, fruits and vegetables and cooking oils and would decrease expenditure on non-alcoholic beverages. Similarly increase in dependency ratio would increase expenditure on cereals and pulses and meat, fish and dairy but it has no effects on other food categories.

\subsubsection{Urban and rural households}

Table 7: Estimated coefficients and expenditure elasticities of food, urban and rural Nepal (1996-2011)

\begin{tabular}{|c|c|c|c|c|c|c|c|c|c|c|c|c|}
\hline \multirow{3}{*}{$\begin{array}{l}\text { Food } \\
\text { Category }\end{array}$} & \multicolumn{7}{|c|}{1996} & \multicolumn{5}{|c|}{2011} \\
\hline & \multirow[b]{2}{*}{$\boldsymbol{\alpha}_{\mathrm{i}}$} & \multicolumn{2}{|l|}{ Urban } & \multicolumn{3}{|l|}{ Rural } & \multicolumn{4}{|c|}{ Urban } & \multicolumn{2}{|c|}{ Rural } \\
\hline & & $\eta_{i}$ & $\mathbf{R}^{2}$ & $\boldsymbol{\alpha}_{\mathrm{i}}$ & $\eta_{i}$ & $\mathbf{R}^{2}$ & $\boldsymbol{\alpha}_{\mathrm{i}}$ & $\eta_{i}$ & $\mathbf{R}^{2}$ & $\boldsymbol{\alpha}_{\mathrm{i}}$ & $\eta_{i}$ & $\mathbf{R}^{2}$ \\
\hline $\begin{array}{l}\text { Overall } \\
\text { Food }\end{array}$ & $\begin{array}{l}2.15 \\
(35.00)\end{array}$ & $\begin{array}{l}0.33 \\
(24.55)\end{array}$ & 0.54 & $\begin{array}{l}1.36 \\
(15.61)\end{array}$ & $\begin{array}{l}0.80 \\
(15.61)\end{array}$ & 0.15 & $\begin{array}{l}2.51 \\
(58.04)\end{array}$ & $\begin{array}{l}0.17 \\
(44.52)\end{array}$ & 0.55 & $\begin{array}{l}2.60 \\
(70.51)\end{array}$ & $\begin{array}{l}0.34 \\
(51.00)\end{array}$ & 0.44 \\
\hline $\begin{array}{l}\text { Cereals and } \\
\text { Pulses }\end{array}$ & $\begin{array}{l}1.30 \\
(26.88)\end{array}$ & $\begin{array}{l}-0.19 \\
(23.05)\end{array}$ & 0.50 & $\begin{array}{l}0.89 \\
(19.60)\end{array}$ & $\begin{array}{l}0.69) \\
(10.61)\end{array}$ & 0.13 & $\begin{array}{l}0.97 \\
(32.11)\end{array}$ & $\begin{array}{l}-0.17 \\
(27.46)\end{array}$ & 0.36 & $\begin{array}{l}1.23 \\
(37.31)\end{array}$ & $\begin{array}{l}0.13 \\
(30.42)\end{array}$ & 0.29 \\
\hline $\begin{array}{l}\text { Meat, Fish } \\
\text { and Dairy }\end{array}$ & $\begin{array}{l}0.23 \\
(7.94)\end{array}$ & $\begin{array}{l}0.67 \\
(4.09)\end{array}$ & 0.03 & $\begin{array}{l}0.09 \\
(4.10)\end{array}$ & $\begin{array}{l}1.09 \\
(1.43)\end{array}$ & 0.04 & $\begin{array}{l}0.42 \\
(21.42)\end{array}$ & $\begin{array}{l}0.33 \\
(15.43)\end{array}$ & 0.14 & $\begin{array}{l}0.32 \\
(15.23)\end{array}$ & $\begin{array}{l}0.64 \\
(8.30)\end{array}$ & 0.10 \\
\hline $\begin{array}{l}\text { Fruits and } \\
\text { Vegetables }\end{array}$ & $\begin{array}{l}0.30 \\
(13.45)\end{array}$ & $\begin{array}{l}0.50 \\
(7.99)\end{array}$ & 0.13 & $\begin{array}{l}0.20 \\
(11.51)\end{array}$ & $\begin{array}{l}0.70 \\
(4.93)\end{array}$ & 0.05 & $\begin{array}{l}0.52 \\
(35.51)\end{array}$ & $\begin{array}{l}0.10 \\
(27.42)\end{array}$ & 0.32 & $\begin{array}{l}0.39 \\
(26.37)\end{array}$ & $\begin{array}{l}0.41 \\
(17.06)\end{array}$ & 0.09 \\
\hline $\begin{array}{l}\text { Cooking } \\
\text { Oils }\end{array}$ & $\begin{array}{l}0.18 \\
(17.03)\end{array}$ & $\begin{array}{l}0.40 \\
(11.42)\end{array}$ & 0.13 & $\begin{array}{l}0.14 \\
(14.97)\end{array}$ & $\begin{array}{l}0.40 \\
(8.46)\end{array}$ & 0.08 & $\begin{array}{l}0.19 \\
(22.27)\end{array}$ & $\begin{array}{l}0.10 \\
(16.64)\end{array}$ & 0.18 & $\begin{array}{l}0.22 \\
(27.07)\end{array}$ & $\begin{array}{l}0.20 \\
(19.96)\end{array}$ & 0.13 \\
\hline
\end{tabular}


Results of intercept coefficients and expenditure elasticities of major food categories in urban and rural Nepal are presented in table 7. Intercept coefficients and expenditure elasticities are all significant at $1 \%$ significance level. Values of $\mathrm{R}^{2}$ are about $55 \%$ for urban households and $45 \%$ for rural households for overall food expenditure. However, for other food categories values of $\mathrm{R}^{2}$ are quite low. Overall food is necessity for both urban and rural households. But urban households have lower expenditure elasticities of food compared to rural households as found in Mittal (2010). Relative to urban households, rural households allocated about $2.5 \%$ and $1.5 \%$ more of their total expenditure towards food in 1996 and 2011 respectively.

Cereals and pulses have expenditure elasticities less than 0 for urban households in both 1996 and 2011. It means they are inferior. 10\% increase in total expenditure would decrease expenditure on cereals and pulses by $1.9 \%$ and $1.7 \%$ in 1996 and 2011 respectively for urban households. However for rural households cereals and pulses were necessities as they would increase expenditure on them by $6.9 \%$ and $1.3 \%$ in 1996 and 2011 respectively with $10 \%$ increase in total expenditure. Meat and dairy products were necessities for urban households. For rural households they were luxuries in 1996 and necessities in 2011 as expenditure elasticities decreased from 1.09 to 0.64 . Fruits and vegetables as well as cooking oils were necessities for both rural and urban households.

\subsubsection{Male and female headed households}

Table 8: Estimated coefficients and expenditure elasticities of food, male and female headed households of Nepal (1996-2011)

\begin{tabular}{|c|c|c|c|c|c|c|c|c|c|c|c|c|}
\hline \multirow{3}{*}{$\begin{array}{l}\text { Food } \\
\text { Category }\end{array}$} & \multirow{2}{*}{\multicolumn{6}{|c|}{$\begin{array}{r}1996 \\
\text { Female }\end{array}$}} & \multicolumn{6}{|c|}{2011} \\
\hline & & & & & & & \multicolumn{4}{|c|}{ Male } & \multicolumn{2}{|c|}{ Female } \\
\hline & $\boldsymbol{\alpha}_{i}$ & $\eta_{i}$ & $\mathbf{R}^{2}$ & $\alpha_{i}$ & $\eta_{i}$ & $\mathbf{R}^{2}$ & $\alpha_{i}$ & $\eta_{i}$ & $\mathbf{R}^{2}$ & $\boldsymbol{\alpha}_{\mathrm{i}}$ & $\eta_{i}$ & $\mathbf{R}^{2}$ \\
\hline verall & 1.76 & 0.64 & 0.35 & 1.75 & 0.59 & 0.36 & 2.67 & 0.25 & 0.56 & 2.43 & 0.33 & 0.48 \\
\hline Food & (51.43) & $(28.27)$ & & $(23.31)$ & (13.11) & & $(82.82)$ & $(62.01)$ & & $(44.81)$ & $(32.37)$ & \\
\hline $\begin{array}{l}\text { Cereals } \\
\text { and Pulses }\end{array}$ & $\begin{array}{l}1.20 \\
(28.85)\end{array}$ & $\begin{array}{l}0.43 \\
(20.36)\end{array}$ & 0.28 & $\begin{array}{l}1.17 \\
(14.03)\end{array}$ & $\begin{array}{l}0.34 \\
(9.89)\end{array}$ & 0.27 & $\begin{array}{l}1.20 \\
(42.75)\end{array}$ & $\begin{array}{l}0.01 \\
(36.07)\end{array}$ & 0.39 & $\begin{array}{l}1.20 \\
(25.88)\end{array}$ & $\begin{array}{l}0.04 \\
(21.29)\end{array}$ & 0.35 \\
\hline $\begin{array}{l}\text { Meat, Fish } \\
\text { and Dairy }\end{array}$ & $\begin{array}{l}0.12 \\
(6.18)\end{array}$ & $\begin{array}{l}1.00 \\
(0.09)\end{array}$ & 0.03 & $\begin{array}{l}0.12 \\
(2.83)\end{array}$ & $\begin{array}{l}1.00 \\
(0.05)\end{array}$ & 0.01 & $\begin{array}{l}0.39 \\
(21.89)\end{array}$ & $\begin{array}{l}0.57 \\
(13.87)\end{array}$ & 0.24 & $\begin{array}{l}0.30 \\
(10.86)\end{array}$ & $\begin{array}{l}0.62 \\
(6.29)\end{array}$ & 0.10 \\
\hline $\begin{array}{l}\text { Fruits and } \\
\text { Vegetables }\end{array}$ & $\begin{array}{l}0.23 \\
(14.75)\end{array}$ & $\begin{array}{l}0.70 \\
(7.20)\end{array}$ & 0.06 & $\begin{array}{l}0.19 \\
(6.12)\end{array}$ & $\begin{array}{l}0.73 \\
(2.67)\end{array}$ & 0.04 & $\begin{array}{l}0.45 \\
(36.12)\end{array}$ & $\begin{array}{l}0.27 \\
(26.00)\end{array}$ & 0.15 & $\begin{array}{l}0.44 \\
(21.11)\end{array}$ & $\begin{array}{l}0.27 \\
(14.44)\end{array}$ & 0.15 \\
\hline $\begin{array}{l}\text { Cooking } \\
\text { Oils }\end{array}$ & $\begin{array}{l}0.15 \\
(18.19)\end{array}$ & $\begin{array}{l}0.40 \\
(11.33)\end{array}$ & 0.08 & $\begin{array}{l}0.13 \\
(7.03)\end{array}$ & $\begin{array}{l}0.67 \\
(3.17)\end{array}$ & 0.08 & $\begin{array}{l}0.20 \\
(30.52)\end{array}$ & $\begin{array}{l}0.09 \\
(23.57)\end{array}$ & 0.15 & $\begin{array}{l}0.23 \\
(17.55)\end{array}$ & $\begin{array}{l}0.20 \\
(12.51)\end{array}$ & 0.14 \\
\hline $\begin{array}{l}\text { Alcoholic } \\
\text { Beverages }\end{array}$ & $\begin{array}{l}-0.03 \\
(2.51)\end{array}$ & $\begin{array}{l}1.09 \\
(5.38)\end{array}$ & 0.03 & $\begin{array}{l}-0.03 \\
(1.32)\end{array}$ & $\begin{array}{l}2.00 \\
(2.29)\end{array}$ & 0.02 & $\begin{array}{l}0.10 \\
(9.93)\end{array}$ & $\begin{array}{l}0.25 \\
(6.87)\end{array}$ & 0.03 & $\begin{array}{l}0.02 \\
(1.43)\end{array}$ & $\begin{array}{l}0.79 \\
(0.86)\end{array}$ & 0.02 \\
\hline
\end{tabular}

Estimated intercept coefficients and expenditure elasticities of overall food expenditure for male and female headed households presented in table 8 are statistically significant at $1 \%$ significance level. But they are not significant for 
some of the other food categories. Values of $\mathrm{R}^{2}$ for overall food expenditure range from $35 \%$ to $56 \%$. As discussed above, values of $\mathrm{R}^{2}$ for other food categories are quite low. Overall food was necessity for both male and female headed households. Expenditure elasticity of food is 0.64 in 1996 and 0.25 in 2011 for male headed households. Similarly for female headed households expenditure elasticity of food is 0.59 in 1996 and 0.33 in 2011.

Cereals and pulses, fruits and vegetables and cooking oils were also necessities for both male and female headed households. Their expenditure elasticities are 0.43 , 0.70 and 0.40 respectively for male headed households and $0.34,0.73$ and 0.67 respectively for female headed households in 1996. In 2011 their expenditure elasticities are $0.01,0.27$ and 0.09 respectively for male headed households and $0.04,0.27$ and 0.20 respectively for female headed households. Meat and dairy products have expenditure elasticity 1 for both male and female headed households in 1996 but they are statistically not significant. In 2011, their expenditure elasticity is 0.57 and 0.62 respectively for male and female headed households and is statistically significant indicating they were necessities. Alcoholic beverages were luxuries for both male and female headed households with expenditure elasticities 1.09 and 2.00 respectively in 1996 . However in 2011 their expenditure elasticity is 0.25 for male headed households. For female headed households expenditure elasticity of alcoholic beverages is 0.79 but statistically not significant.

\section{Concluding Remarks}

The study utilized two data-sets NLSS 1995/96 and 2010/11 to analyze changes in food consumption behavior of Nepalese households between the period before and after Maoist conflict. Nepal underwent major socio economic changes during this time. Population increased at an annual rate of 2\% from 1991 to 2011. Average household size decreased from 5.6 to 4.9. Percentage of urban households increased from 21.2 to 33.7 between 1996 and 2011. The incidence of poverty almost halved during the same time. GDP increased at an annual rate of almost $4.5 \%$. Nominal income of households increased at an annual rate of about $10 \%$. Contribution of agriculture towards GDP decreased from $81.2 \%$ in 1991 to $64.3 \%$ in 2011. Share of external sectors; trade and remittance increased in national income. Due to changes in all these factors, it is imperative to find out if there were significant changes in food consumption pattern that has important policy applications.

The results of the study show that there was a structural shift in food consumption behavior of Nepalese households between 1996 and 2011. Household food expenditure and per-capita food expenditure in nominal terms increased at an annual rate of $8.41 \%$ and $9.68 \%$ respectively. This was in line with $10 \%$ annual 
increase in nominal income of Nepalese households. Food budget share declined from $79 \%$ to $67 \%$. As income increases over time it is anticipated that households shift their budget from food that is necessity to other non-food items that are luxuries. Similarly, rural households had larger food budget share than urban households during both 1996 and 2011. Female headed households had higher percapita food expenditure but lower mean food expenditure than male headed households.

Among food categories, cereals and pulses have the highest food budget share followed by meat and dairy products, fruits and vegetables and cooking oils. But budget share of cereals and pulses declined from 1996 to 2011 as households diversified food consumption. Budget share for food items like meat, fish and dairy, fruits and vegetables, cooking oils increased. There is also a significant rise in budget share of miscellaneous food products indicating increasing consumption of commercial products like noodles, biscuits and food taken away from home. Budget share of cereals and pulses is high among low expenditure group while budget share for other major food items is high among high expenditure groups. This indicates that as income increases households replace cheap starchy food with high value nutritious food. However, decreasing budget share of cereals and pulses and increasing share of meat and dairy and fruits and vegetables over time even among low expenditure households indicates change in tastes and preferences.

Regression results show that food was a normal good during both 1996 and 2011. But expenditure elasticity of food declined from 1996 to 2011. It was lower for high expenditure group compared to that of low expenditure group during both periods. Among major food categories, cereals and pulses, fruits and vegetables, cooking oils, and sweets and spices were necessities. Some of the food items like meat and dairy products and alcoholic beverages were luxuries in 1996 and necessities in 2011. Non Alcoholic beverages and miscellaneous food products were luxuries during both periods though their expenditure elasticities declined. Tobacco and Tobacco products became inferior in 2011 while they were necessities in 1996.

Effects of demographic variables; family size, household location, gender of household head and remittance income on food expenditure are also investigated. There are diseconomies of scale in food expenditure as additional food expenditure increased with increase in family size. This result is contrary to some of the other studies; Banskota et al., (1986) and Al-Habashneh and Al-Majali (2014) as they have found economies of scale in food. However, these studies have found diseconomies of scale in some particular food commodities and other non-food items. Expenditure elasticities of overall food and major food categories are higher for rural households compared to urban households. Cereals and pulses were 
inferior for urban households but necessities for rural households during 1996 and 2011. Meat and dairy products, fruits and vegetables and cooking oils were necessities for both partitions.

One of the main limitations of this study is that the values of $\mathrm{R}^{2}$ for estimates of the model are quite low. Low values of $\mathrm{R}^{2}$ means the independent variables used in the study do not explain the variation in food expenditure of households sufficiently. Since this study has used cross section data, prices for food items are assumed to be same for each household. Relaxing this assumption would most likely contribute for the increase in values of $\mathrm{R}^{2}$. NLSS data for the year 2003/04 is omitted so as to compare the food expenditure behavior of households before and after the Maoist conflict. However, using the data from this particular year could have provided further important information regarding changing food expenditure pattern. Addressing these limitations could be the scope for further studies.

The findings of the study are important to devise effective food policies. Food is a necessity commodity with households allocating large part of their budget towards food expenditure. Food budget share is even higher among poor households. Therefore, special attention is required while designing tax policies on food as most of the tax on food is borne by poor households. Rural as well as poor households consume relatively more of cereals and pulses and less of meat, dairy products, fruits and vegetables. This leads to disparity in nutrition and health status among these households. Therefore, the government has to make efforts to make all types of food items accessible to these households. Declining consumption of cereals and pulses and increasing consumption of fruits and vegetables, meat and dairy products, cooking oils and miscellaneous food products means supply of food has to be revised. Though cereals and pulses are staple food of Nepal, production of other food items have to be increased to enhance their supply and address the problems of food security. 


\section{References}

Al-Habashneh, F., \& Al-Majali, K. (2014). Estimating the engel curves for household expenditure in Jordan from 2010 to 2011. European Scientific Journal, 10(2), 267-282.

Banks, J., Blundell, R., \& Lewbel, A. (1997). Quadratic engel curves and consumer demand. The Review of Economics and Statistics, 79(4), 527-539.

Banskota, K., Booth, R., Johnson, S., Pryor, S., \& Stampley, G. L. (1986). An analysis of the expenditure patterns of Jamaican households. Paper Presented at the $18^{\text {th }}$ West Indian Agricultural Economics Conference. Jamaica: University of West Indies.

CBS. (2011). Nepal living standard survey, statisticaal report (Vol. II). Kathmandu: Central Bureau of Statistics.

Deaton, A., \& Muellbauer, J. (1980). An Almost Ideal Demand System. The American Economic Review, 70(3), 312-326.

FAO; IFAD; WFP. (2013). The state of food insecurity in the world. The multiple dimension of food security. Rome: FAO.

George, P., \& King, G. (1971). Consumer demand for food commodities in the United States with projections for 1980. Giannini Foundation Monograph Number 26, 1-161.

Gupta, A., \& Mishra, D. K. (2014). Food consumption pattern in rural India: A regional perspective. Journal of Economic \& Social Development, 10(1), 116.

Khan, A. H., \& Khalid, U. (2010). Household Consumption Pattern in Pakistan: Evidence from Household Data. NUST Journal of Business and Economics, $3(1), 1-14$.

Kiani, A. K. (2013). Forecasting the future consumption: A case study for Pakistan. Euro-Asian Journal of Economics and Finance, 1(1), 41-50.

Kumar, P., Kumar, A., Parappurathu, S., \& Raju, S. (2011). Estimation of demand elasticity for food commodities in India. Agricultural Economics Research Review, 24(1), 1-14.

Mittal, S. (2010). Application of the QUAIDS model to the food sector in India. Journal of Quantitative Economics, 8(1), 42-54.

Molina, J. (1994). Food demand in Spain: An application of almost ideal demand system. Journal of Agriculture Economics, 45(2), 252-258. 
NLSS. (1996). Nepal living standards survey report 1996 (Vol. I). Kathmandu: Central Bureau of Statistics.

NLSS (2011). Nepal living standards survey report 2011 (Vol. I). Kathmandu: Central Bureau of Statistics.

Pradhan, J., \& Tuwade, I. (1997). Food consumption pattern in Srilanka: An application of LA/AIDS Model. 41st Annual Conference of the Australian Agricultural and Resource Economics Society, Gold Coast, (pp. 1-15).

Prais, S., \& Houthhakker, H. (1955). The analysis of family budgets (Vol. 4). Cambridge: Cambridge University Press.

Regmi, H. R. (2016). Food and nutrition security; A status report of Nepal. Asia and Pacific Commission on Agricultural Statistics. Thimpu: Ministry of Agricultural Development Nepal.

USAID Nepal. (2017). Agriculture and food security. Retrieved from USAID From the American People: https://www.usaid.gov/nepal/agriculture-and-foodsecurity.

World Bank. (2017). Data bank: World development indicators. Retrieved from The World Bank IBRD-IDA: http://databank.worldbank.org/data/reports. aspx? source $=2 \&$ country $=$ NPL. 